\title{
Evaluasi Ketersediaan Hara pada Dua Lokasi Budidaya Tanaman Serewangi di Lamteuba Kecamatan Seulimuem Aceh Besar
}

\author{
(Evaluation of Nutrient Availability in Two Locations of Serewangi Cultivation in \\ Lamteuba, Seulimuem District, Aceh Besar)
}

\author{
Teuku Ansari ${ }^{1}$, Helmi ${ }^{1}$, Yadi Jufri ${ }^{1 *}$ \\ ${ }^{1}$ Program Studi Ilmu Tanah, Fakultas Pertanian, Universitas Syiah Kuala \\ *Corresponding author: emailpembimbingutama@unsyiah.ac.id
}

\begin{abstract}
Abstrak. Tanah adalah mekanisme karakteristik untuk pengembangan tanaman. Tanah memberi unsur-unsur hara sebagai makanan tanaman untuk perkembangannya. Tanah terbentuk dari bahan berupa mineral dan bahan organik, air dan udara yang tersusun dalam ruangan yang membentuk tubuh tanah. Hasil jalannya proses perkembangan pembentukan tanah, maka terbentuklah perbedaan sifat kimia tanah, fisik, biologi dan morfologi tanah (Hakim, et al, 1986). Tanah yang diusahakan untuk bidang pertanian memiliki tingkat kesuburan yang berbeda-beda. Adapun tujuan dari penelitian ini adalah untuk mengevaluasi kandungan hara pada dua lokasi budidaya tanaman serewangi yang menyebabkan perbedaan pertumbuhan di dua lokasi tersebut. Pengelolaan tanah secara tepat merupakan faktor penting dalam menentukan pertumbuhan dan hasil tanaman yang akan diusahakan. Penentuan ketersediaan hara tanah diawali dengan survey pendahuluan, pengambilan sampel tanah dilapangan dan selanjutnya dilakukan analisis sampel tanah dilaboratorium dan terakhir dilakukan pengolahan data dengan mengacu pada tabel kriteria interpretasi sifat-sifat kimia tanah menurut puslittanak (2003). Berdasarkan hasil analisis laboratorium, menunjukkan bahwa kandungan hara di dua lokasi budidaya tanaman serewangi tidak menunjukkan perbedaan yang jauh berbeda, relatif hampir sama dengan kandungan hara yang rendah. Perbedaan pertumbuhan tanaman serewangi pada dua lokasi budidaya disebabkan oleh perbedaan topografi lahan yang agak berbeda serta cara pengelolaannya, yang menyebabkan perbedaan pertumbuhan tanaman di dua lokasi tersebut.
\end{abstract}

Kata kunci: Evaluasi, ketersediaan hara, budidaya, tanaman serewangi.

\begin{abstract}
Soil is a characteristic mechanism for plant development. Soil provides nutrients as plant food for its development. Soil is formed from materials in the form of minerals and organic matter, water and air which are arranged in a room that forms the body of the soil. As a result of the development process of soil formation, differences in soil chemical, physical, biological and morphological properties of soil are formed (Hakim, et all, 1986). Soil cultivated for agriculture has different levels of fertility. The purpose of this study was to evaluate the nutrient content of the two locations of Serewangi cultivation that caused differences in growth in the two locations. Proper soil management is an important factor in determining the growth and yield of plants to be cultivated. Determination of soil nutrient availability begins with a preliminary survey, taking soil samples in the field and then analyzing soil samples in the laboratory and finally processing data by referring to the table of interpretation criteria for soil chemical properties according to Research Center for Research and Development (2003). Based on the results of laboratory analysis, it was shown that the nutrient content in the two locations of Serewangi cultivation did not show much difference, relatively close to the same with low nutrient content. The difference in the growth of the serewangi plants at the two cultivation locations was caused by the slightly different topography of the land and the way of management, which caused differences in plant growth in the two locations.
\end{abstract}

Keywords: Evaluation, nutrient availability, cultivation, serewangi plants.

\section{PENDAHULUAN}

Tanah adalah media untuk pengembangan tanaman. Tanah dapat memberi unsur hara sebagai makanan untuk keberlangsungan pertumbuhan tanaman. Tanah terbentuk dari bahanbahan mineral seperti bahan organik, air dan udara, dari hasil jalannya proses perkembangan pembentukan tanah, maka terbentuklah perbedaan sifat kimia tanah, fisik, biologi dan morfologi tanah (Hakim, et al, 1986).

Tanah yang digunakan untuk lahan pertanian memiliki tingkat kesuburan yang berbedabeda. Dengan melakukan pengelolaan secara tepat merupakan faktor terpenting untuk dapat 
mennentukan hasil dan pertumbuhan tanaman yang akan dibudidayakan, unsur hara yang dibutuhkan oleh tanaman dapat ditentukan oleh kemampuan tanah dalam meyediakan hara untuk tanaman dan pada umumnya tidak sepenuhnya dapat terpenuhi (PPT, 1999).

Serewangi (Cymbopogon nardus L.) merupakan salah satu tanaman pokok dari famili Gramineae yang umumnya dimanfaatkan dalam berbagai usaha wewangian, kecantikan, makanan, minuman dan obat-obatan. Serewangi juga dapat digunakan sebagai bahan pestisida alami untuk mengendalikan hama dan penyakit tanaman (Damanik, 2007).

Tanaman serewangi saat ini sedang dikembangkan karena umumnya memiliki kondisi pertumbuhan yang lebih sederhana sehingga tidak sulit dikembangkan pada berbagai jenis-jenis tanah. Tanah latosol merupakan jenis tanah terbesar yang menguasai daratan di Indonesia dengan luas tanah 84,63 juta ha (Djaenudin 2008). Peluang kemajuan budidaya serewangi pada tanah latosol sangat besar, namun ada beberapa kendala, yaitu tingkat $\mathrm{pH}$ yang rendah sehingga unsur hara kurang dapat diakses dan menyebabkan retensi hara oleh tanaman menjadi terbatas (Perdanatika et al. 2018). Hal ini dapat mempengaruhi produktivitas tanaman. Upaya untuk dapat meningkatkan kualitas pertumbuhan tanaman serewangi maka perlu untuk dilakukannya pemupukan pada tanah latosol. Pemupukan juga harus mempertimbangkan jenis tanah dan juga tanaman yang akan di budidayakan karena masing-masing tanaman budidaya memiliki karakteristik yang berbeda-beda, sehingga respon tanaman terhadap pupuk juga berbeda.

Di desa Lamteuba Kecamatan Seulimum Aceh Besar sudah di lakukan pembudidayaan tanaman serewangi, salah satunya yaitu lahan milik lembaga dewan dakwah Aceh yang dikelola oleh lembaga itu sendiri, lahan tersebut terletak pada area hutan yang telah diberikan izin untuk dijadikan area perkebunan, Menurut peraturan mentri kehutanan nomor p.55/menhut-II/2011 yaitu area perkebunan harus berada pada kawasan yang tidak produktif dan bukan merupakan kawasan hutan lindung (widianto et al., 2013).

Lahan yang telah ditanami serewangi seluas 2 hektare dan miliki topografi yang berbeda yaitu pada lokasi pertama memiliki kemiringan lahan berkisar $15^{\circ}$ (landai) dengan ketinggian lahan 429,2 mdpl sedangkan pada lokasi kedua kemiringan lahan berkisar $22^{\circ}$ (agak curam) dengan ketinggian lahan 434,0 mdpl, kemiringan lereng sangat berpengaruh terhadap unsur hara yang ada pada tanah, jika kemiringan lereng semakin curam, maka proses pencucian akan sangat tinggi sehingga dapat mengangkut tanah serta hara, mengakibatkan tanah mengalami penurunan kualitasnya, (Bermana, 1978).

Pada dua lokasi yang sudah di tanami serewangi adanya perbedaan pertumbuhannya, pada lokasi yang pertama yang bertopografi landai pertumbuhan serewangi cukup bagus, namun pada lahan lokasi kedua yang memiliki topografi agak curam pertumbuhan serewangi tidak tumbuh dengan bagus, hal ini ditunjukan dengan banyaknya terdapat alang alang yang tumbuh dan juga pertumbuhan serewangi yang tumbuh kerdil pada lokasi kedua.

Berdasarkan alasan di atas, penting untuk melakukan evaluasi ketersediaan hara pada lahan serewangi tersebut, dengan menilai ketersediaan hara adalah cara untuk mengetahui masalah keharaan di tanah dan selanjutnya dapat direkomendasikan proses pemupukan (Dikti, 1991). Cara yang dapat digunakan untuk menentukan ketersediaan hara pada suatu tanah adalah melalui metodologi analisis tanah. Ada beberapa parameter kimia tanah yang digunakan dalam penelitian ini untuk mengetahui ketersediaan hara pada kedua lahan serewangi, yaitu C-organik, $\mathrm{N}$ - total, P- tersedia, P- total, K- dd, pH dan Ktk serta untuk parameter fisika tanah yaitu tekstur tanah. Penelitian ini bertujuan untuk mengevaluasi ketersediaan hara pada 2 lokasi budidaya tanaman serewangi di Desa Lamteuba Kecamatan Selimum Aceh Besar. 


\section{METODE PENELITIAN}

Penelitian ini telah dilaksanakan pada lahan serewangi milik Lembaga Dewan Dakwah Aceh di Lamteuba Kecamatan Seulimum Aceh Besar. Adapun untuk analisis tanah dilakukan di Laboratorium Balai Pengkajian Teknologi Pertanian Aceh. Penelitian ini di mulai dari bulan Januari 2020 sampai dengan Agustus 2021.

\section{Pengambilan Sampel Tanah}

Tahapan persiapan penelitian ini meliputi survey awal kelokasi yang akan dijadikan tempat penelitian sekaligus untuk memperoleh informasi terhadap kondisi dilapangan yang meliputi letak lokasi penelitian, pengambilan sampel tanah dilakukan pada lahan serewangi milik Lembaga Dewan Dakwah Aceh Besar di dua lokasi berbeda dengan jarak antara kedua lokasi yaitu sekitar 100 meter. Sampel tanah yang diambil yaitu sampel tanah pada kedalaman 0-20 cm (top soil) dan kedalaman 21-40 cm (sub Soil). Tujuan pengambilan sampel tanah pada lapisan top soil dan sub soil yaitu dikarenakan kedalaman akar tanaman serewangi dapat mencapai pada kedalaman $30 \mathrm{~cm}$, maka perlu untuk mengetahui ketersediaan hara pada lapisan top soil dan sub soil. Pengambilan sampel tanah untuk tanaman serewangi di ambil disekitar tanaman.

Titik sampel ditentukan menggunakan teknik Random sampling yaitu teknik mengambil sampel secara acak. Selanjutnya sampel yang didapatkan dengan melakukan proses pengeboran tanah dengan kedalaman 0-20 cm dan 21-40 cm, lalu diambil titik koordinatnya dengan menggunakan GPS. Menentukan tempat pengambilan sampel tanah sebanyak 10 titik pada dua lokasi berbeda, pada lokasi pertama di ambil 5 titik dan lokasi kedua di ambil 5 titik lalu di kompositkan menjadi 1 sampel tanah. Di setiap lokasi di lakukan ulangan pada titik yang sama untuk mengambil sampel tanah pada kedalaman 21-40 $\mathrm{cm}$ sehingga didapatkan 4 sampel tanah. Masing-masing sampel tanah dimasukkan kedalam kantung plastik kemudian diberi kode. Dicatat letak koordinat titik pengambilan sampel tanah, selanjutnya dilakukan Analisis sifat kimia tanah dan fisika tanah di laboratorium.

Tabel 1. Pengambilan Titik Sampel

\begin{tabular}{lccccc}
\hline No & Lahan Serewangi & Jumlah titik & \multicolumn{2}{c}{ Kedalaman Sampel $(\mathrm{cm})$} & Jumlah Sampel \\
\cline { 4 - 5 } & Seluas 2 Hektare & & $0-20$ & $20-40$ & \\
\hline 1 & Lokasi 1 & 5 & 1 & 1 & 2 \\
2 & Lokasi 2 & 5 & 1 & & 4 \\
Total & & & & & 2 \\
\hline
\end{tabular}

\section{Analisis Tanah di Laboratorium}

Tanah yang di analisis dilaboratorium yaitu untuk menentukan sifat kimia tanah dan fisika tanah. Sampel tanah diproses terlebih dahulu untuk dikering anginkan, selanjutnya tanah tersebut dihaluskan dan ditumbuk, selanjutnya diayak dengan ayakan ukuran 20 mess. Aspek analisis dan metode yang digunakan dapat dilihat pada Tabel 2.

\section{Pengolahan Data Hasil Laboratorium}

Data yang didapatkan dari hasil analisis tanah dilaboratorium di olah berdasarkan tabel kriteria penilaiaan sifat-sifat kimia tanah, sehingga diketahui permasalahan yang terjadi sehingga dapat menggambarkan ketersediaan hara pada kedua lokasi budidaya tanaman serewangi. 
Tabel 2. Aspek Analisis dan Metode Sifat Kimia Tanah dan Fisika Tanah

\begin{tabular}{|c|c|}
\hline Aspek Analisis & Metode \\
\hline $\mathrm{pH}\left(\mathrm{H}_{2} \mathrm{O}\right)$ & Elektrometrik \\
\hline C- organik & Walkley dan Black \\
\hline $\mathrm{N}$ - total & Kjeldhal \\
\hline P- tersedia & Bray I \\
\hline P- total & Ekstraksi $\mathrm{HCl} 25 \%$ \\
\hline $\mathrm{K}$ - dd & $1 \mathrm{~N} \mathrm{NH}_{4} \mathrm{OAc} \mathrm{pH} 7$ \\
\hline KTK & $1 \mathrm{~N} \mathrm{NH}_{4} \mathrm{OAc} \mathrm{pH} 7$ \\
\hline Tekstur & Hidrometer/Pipet \\
\hline
\end{tabular}

Sumber : Puslittanak $\left.(1999) ;{ }^{2}\right)=$ WOLF $(1982)$

\section{HASIL DAN PEMBAHASAN}

\section{Analisis Kimia dan Fisika Tanah}

Hasil analisis lahan serewangi berupa pH, P-tersedia (ppm), P-total (mg/100 g), KTK (me/100 g), C-organik (\%), K-dd $\mathrm{cmol}(+) / \mathrm{kg}, \mathrm{N}$-total dan Tekstur diperoleh hasil sebagai berikut

Tabel 3. Hasil Analisis Sifat Kimia Tanah Pada Lahan Serewangi di Lamteuba

\begin{tabular}{llllllll}
\hline Kode Sampel & $\mathrm{pH} \mathrm{H}_{2} \mathrm{O}$ & $\begin{array}{l}\text { P-Tersedia } \\
(\mathrm{ppm})\end{array}$ & $\begin{array}{l}\text { P-Total } \\
(\mathrm{mg} / 100 \mathrm{~g})\end{array}$ & $\begin{array}{l}\text { C-Organik } \\
(\%)\end{array}$ & $\begin{array}{l}\text { KTK } \\
(\mathrm{me} / 100 \mathrm{~g})\end{array}$ & $\begin{array}{l}\text { Kdd } \\
\mathrm{Cmol}(+) / \\
\mathrm{kg}\end{array}$ & $\begin{array}{l}\text { N-Total } \\
(\mathrm{Kjhed} \\
\mathrm{al})\end{array}$ \\
\hline
\end{tabular}

Lahan Serewangi Lokasi Pertama ( Pertumbuhan Bagus )

\begin{tabular}{|c|c|c|c|c|c|c|}
\hline L1 Top Soil & $5,47^{\mathrm{m}}$ & $24,14^{\mathrm{r}}$ & $7,84^{\mathrm{sr}}$ & $2,19^{\mathrm{s}}$ & $12,15^{\mathrm{r}}$ & $0,63^{\mathrm{t}}$ \\
\hline L1 Sub Soil & $5,51^{\mathrm{m}}$ & $21,48^{\mathrm{r}}$ & $5,63^{\mathrm{sr}}$ & $1,53^{\mathrm{r}}$ & $4,35^{\mathrm{sr}}$ & $0,59^{\mathrm{s}}$ \\
\hline
\end{tabular}

Lahan Serewangi Lokasi Kedua ( Pertumbuhan Tidak Bagus)

\begin{tabular}{|c|c|c|c|c|c|c|c|}
\hline L2 Top Soil & $5,63^{\mathrm{am}}$ & $23,83^{r}$ & $8,03^{\mathrm{sr}}$ & $1,56^{\mathrm{r}}$ & $13,15^{\mathrm{r}}$ & $0,63^{\mathrm{t}}$ & $0,11^{\mathrm{r}}$ \\
\hline L2 Sub Soil & $5,68^{\mathrm{am}}$ & $22,56^{\mathrm{r}}$ & $3,23^{\mathrm{sr}}$ & $1,31^{\mathrm{r}}$ & $19,05^{\mathrm{s}}$ & $0,70^{t}$ & $0,07^{r}$ \\
\hline
\end{tabular}

Sumber : Hasil Analisis Kimia Tanah Laboratorium Balai Pengkajian Teknologi Pertanian

Keterangan : Kriteria Penilaian Data Analisis Tanah; $\mathrm{m}=$ masam; am = agak masam; $\mathrm{sr}=$ sangat rendah; $\mathrm{r}=$ rendah $; \mathrm{s}=$ sedang; $\mathrm{t}=$ tinggi; $\mathrm{st}=$ sangat tinggi .

Tabel 4. Hasil Analisis Fisika Tanah Pada Lahan Serewangi di Lamteuba

\begin{tabular}{lcccc}
\hline Kode Sampel & Pasir $(\%)$ & Debu $(\%)$ & Liat ( \%) & Keterangan \\
\hline L1 Top Soil & 40,82 & 28,57 & 30,61 & Lempung Berliat \\
L2 Top Soil & 38,78 & 26,53 & 34,69 & Lempung Berliat \\
\hline
\end{tabular}

Sumber; Hasil Analisis Fisika tanah Laboratorium Balai Pengkajian Teknologi Pertanian

\section{Tekstur}

Hasil analisis tekstur dari kedua lokasi menunjukan bahwa pada lokasi pertama nilai tekstur pada pasir $40,8 \%$, debu $28,5 \%$, liat 30,6\% tergolong pada kategori lempung berliat, sedangkan pada lokasi kedua nilai kandungan pasir 38,7\%, debu 26,5\%, liat 34,6\% tergolong pada kategori lempung berliat. Berdasarkan tabel kriteria kesesuaian lahan pada tanaman 
serewangi tanah bertekstur lempung berliat sangat sesuai untuk ditanami serewangi karena tekstur tanahnya agak halus yang membuat daya serap lebih kuat. Hal ini sejalan dengan pernyataan Hanafiah (2012), yang menyatakan bahwa apabila debu memiliki luas permukaan yang lebih besar dari pada pasir, maka tanah tersebut dapat memegang dengan kuat air dan hara yang tersedia bagi tanaman.

Menurut Hasibuan (2008), tanah yang terbentuk dari batuan dan mineral yang bertahan lama akan menghasilkan partikel-partikel tanah yang memiliki ukuran yang berbeda-beda dari ukuran kasar seperti batu dan pasir hingga ukuran halus seperti partikel tanah.

Tabel 5. Tabel Kriteria Interpretasi Sifat Kimia Tanah Lokasi Penelitian

\begin{tabular}{ccrrrr}
\hline No & $\begin{array}{c}\text { Parameter } \\
\text { Kimia Tanah }\end{array}$ & L1 Top Soil & L1 Sub Soil & L2 Top Soil & L2 Sub Soil \\
\hline 1. & C - organik & Sedang & Rendah & Rendah & Rendah \\
2. & N - total & Rendah & Rendah & Rendah & Rendah \\
3. & P - tersedia & Rendah & Rendah & Rendah & Rendah \\
4. & P - Total & Sangat Rendah & Sangat Rendah & Sangat Rendah & Sangat Rendah \\
5. & K dd & Tinggi & Sedang & Tinggi & Tinggi \\
6. & KTK & Rendah & Sangat Rendah & Rendah & Sedang \\
7. & pH & Masam & Masam & Agak Masam & Agak Masam \\
\hline
\end{tabular}

Sumber; Hasil Penelitian Kimia Tanah Laboratorium Balai Pengkajian Teknologi Pertanian

pH

Hasil $\mathrm{pH}-\mathrm{H}_{2} \mathrm{O}$ pada kedua lokasi, nilai $\mathrm{pH}$ pada lokasi pertama pada lapisan top soil rata-rata 5,47 (masam), dan $\mathrm{pH}$ pada lapisan sub soil rata-rata 5,5 (masam). Sedangkan pada lokasi kedua $\mathrm{pH}$ pada lapisan top soil rata-rata 5,63 (agak masam), dan $\mathrm{pH}$ pada lapisan sub soil rata-rata 5,68 (agak masam). Penyebab rendahnya $\mathrm{pH}$ tanah pada kedua lokasi diduga karena tidak adanya dilakukan pengolahan lahan dan juga pemupukan, sehingga tanah tersebut belum dimanfaatkan dengan maksimal dan tidak adanya penambahan bahan organik yang fungsinya untuk membuat $\mathrm{pH}$ tanah netral. Sehingga kedua lokasi tersebut didapati $\mathrm{pH}$ tanah yang masam dan agak masam, tanah yang masam maupun agak masam seringkali menjadi penyebab utama menurunya produktifitas berbagai jenis tanaman. Menurut Atmaja et al., (2017) penggunaan bahan organik dapat meningkatkan $\mathrm{pH}$, ketika bahan organik telah terurai, maka pada saat itu bahan organik yang termineralisasi akan melepaskan mineralnya, sebagai kation esensial.

\section{C- organik}

Hasil C- organik pada lokasi pertama nilai rata rata pada lapisan top soil 2,19 (sedang), dan pada lapisan sub soil rata-rata 1,53 (rendah), sedangkan pada lokasi kedua nilai C-organik pada lapisan top soil rata-rata 1,56 (rendah), dan pada lapisan sub soil rata-rata 1,31 (rendah) keduanya tergolong rendah, hal ini diduga pada kedua lokasi tersebut tidak adanya dilakukan proses pemupukan, seperti yang kita tahu dengan adanya dilakukan pemupukan maka akan dapat meningkatkan kandungan C- organik pada tanah. Hitmatullah dan sukarman (2007) menyatakan bahwasanya penurunan $\mathrm{C}$ - organik disebabkan karena adanya proses dekomposisi yang dilakukan oleh mikroorganisme tanah Menurut Notohadiprawiro (2006), untuk mengatasi masalah tanah masam dan C- organik yang rendah adalah dengan memanfaatkan bahan organik sebagai ligan. Selanjutnya, tanah yang bagus diharapkan dapat mengatasi masalah ini dengan memanfaatkan bahan-bahan alami, misalnya seperti pupuk sapi, sisa-sisa tumbuhan karena jika 
tidak dilakukan perbaikan maka akan sulit tanah tersebut dimanfaatkan, terutama dalam budidaya tanaman.

\section{N- total}

Hasil N-total pada lokasi pertama nilai rata-rata pada lapisan top soil 0,12 (rendah), dan pada lapisan sub soil 0,9 (rendah), sedangkan pada lokasi kedua nilai rata-rata pada lapisan top soil 0,11 (rendah), dan pada lapisan sub soil 0,7 (rendah). Rendahnya nitrogen di suatu lahan diduga akibat laju dekomposisi rendah dan $\mathrm{pH}$ tanah pada lokasi yang tergolong masam sehingga mikroorganisme tidak dapat melakukan pergerakan dan bekerja secara optimal. Suwondo et al., (2010) menyatakan bahwa perkembangan mikroorganisme sangat dipengaruhi oleh kondisi $\mathrm{pH}$ tanah. Pada tanah yang memiliki $\mathrm{pH}$ asam, perkembangan mikroorganisme akan sangat rendah.

Pergerakan dan perkembangan mikroorganisme di dalam tanah dapat dipengaruhi oleh $\mathrm{pH}$ tanah, mikroorganisme di dalam tanah akan bergerak lambat apabila $\mathrm{pH}$ tanah bersifat asam, dan mampu sangat cepat apabila $\mathrm{pH}$ tanah bersifat netral, penyebab inilah yang membuat kandumgan nitrogen pada lahan-lahan hutan lebih rendah dari pada lahan di perkebunan (Barchia, 2009).

\section{P- total}

Hasil P-total pada lokasi pertama pada lapisan top soil rata-rata 7,84 (sangat rendah), dan pada lapisan sub soil rata-rata 5,63 (sangat rendah), sedangkan pada lokasi kedua nilai Ptotal pada lapisan top soil rata-rata 8,03 (sangat rendah), dan pada lapisan sub soil rata-rata 3,23 (sangat rendah). Kandungan p-total pada kedua lahan tersebut tergolong sangat rendah. Rendahnya P-total pada kedua lahan tersebut diduga karena kandungan bahan organik sangat rendah dan dipengaruhi oleh $\mathrm{pH}$ yang masam dan agak masam. Tanah yang masam memiliki kandungan $\mathrm{Fe}$ dan $\mathrm{Al}$ yang relatif lebih tinggi di dalam tanah, Hal ini sejalan dengan penelitian Gunawan (2013) rendahnya kandungan hara P-total dapat disebabkan oleh rendahnya kandungan bahan organik yang terdapat didalam tanah pada lokasi penelitian , Upaya yang dapat dilakukan untuk meningkatkan ketersediaan unsur hara P-total pada lokasi penelitian yaitu dengan memberikan pupuk fosfat dan kalium sesuai dengan kebutuhan dan perhitungan pada tanaman dan diharapkan ketersediaan unsur hara dapat meningkat.

\section{P- tersedia}

Hasil P- tersedia pada lokasi pertama nilai $\mathrm{P}$-tersedia pada lapisan top soil rata-rata 24,14ppm (rendah), dan pada lapisan sub soil rata-rata 21,48ppm (rendah), sedangkan pada lokasi kedua nilai P-tersedia pada lapisan top soil rata-rata 23,83ppm (rendah), dan pada lapisan sub soil rata-rata 22,56ppm (rendah), Rendahnya $\mathrm{P}$ - tersedia di kedua lahan serewangi dapat diduga akibat lahan tersebut memiliki $\mathrm{pH}$ tanah yang masam sehingga fosfor tidak tersedia dan lahan tersebut mengandung $\mathrm{Al}$ dan Fe serta diduga karena tidak adanya pemeberian pupuk pada lahan yang ditanamani serewangi. Sutandi (2011) menyatakan bahwa jika Al dan Fe meningkat maka akan dapat mengikat $P$ sehingga didalam tanah akan berkurang ketersediaannya.

Fungsi penting P- tersedia pada tanaman saat ini adalah sebagai fotosintesis, pernapasan, pergerakan dan kapasitas energi, pembelahan sel dan pembesaran sel serta prosesproses didalam tanaman lainya. Karena $\mathrm{P}$ dibutuhkan oleh tanaman dalam jumlah yang cukup besar, maka P dikenal sebagai nutrisi bagi tanaman dalam skala besar. Di dalam tanah Ptersedia dalam berbagai bentuk persenyawaan, yang sebagian besar tidak dapat diakses oleh tanaman. Sebagian besar pupuk yang diberikan ke tanah tidak dapat dimanfaatkan oleh tanaman (Winarso, 2005). 
Izuddin (2012) menyatakan bahwa P yang ada didalam tanah tersebut kemungkinan berasal dari bahan-bahan alami seperti pupuk buatan, dan kandungan mineral yang ada didalam tanah. Fosfor yang diperoleh didalam tanah, sebagian besar terdapat pada tanah-tanah masam, kapur dapat ditambahkan sehingga $\mathrm{pH}$ mampu untuk meningkat dan unsur fosfor dapat diperoleh dari senyawa pengikat seperti Fe dan $\mathrm{Al}$. Bentuk yang dapat dijangkau oleh tumbuhan yaitu sebagai partikel fosfat. Hanafiah (2007) menyatakan bahwa, dibandingkan dengan unsur hara nitrogen, komponen fosfor mampu terbuka lebih cepat karena dibatasi oleh kation tanah dan terfiksasi pada permukaan positif koloid tanah. P- tersedia yang ideal berada pada rentang $\mathrm{pH} 6,00-7,00$.

\section{K- dd}

Hasil K- dd pada lokasi pertama pada lapisan top soil rata-rata 0,63 (tinggi), dan lapisan sub soil rata-rata 0,59 (sedang), sedangkan pada lokasi kedua pada lapisan top soil rata-rata 0,63 (tinggi), dan pada lapisan sub soil rata- rata 0,70 (tinggi), tinggi nya k-dd pada kedua lokasi tersebut diduga karena sumbangan seresahnya lebih banyak, sumbangan serasah ini dihasilkan secara alami dari berbagai jenis vegetasi yang tumbuh di atasnya mulai dari rerumputan, semak belukar, lumut hingga berbagai jenis pohon besar yang tumbuh. Foth (1994) menyatakan bahwa sisa-sisa tumbuhan dan akar tanaman dapat memberikan bahan mentah untuk perombakan mikrobial yang berisi 50\% karbon. Akar tanaman yang hidup dalam waktu singkat serta seresah tanaman akan mendukung besarnya humifikasi bahan organik. Dan juga unsur hara alami pada kedua lokasi tersebut tidak mudah tercuci di karenakan tanah pada kedua lokasi tersebut bertekstur lempung berliat karena mampu mengikat air dan hara dengan kuat. Hal ini di dukung dengan pernyataan Hanafiah (2012) yang menyatakan bahwa karena debu memiliki luas permukaan yang lebih besar dari pada permukaan pasir, maka tanah tersebut akan dapat memegang air dan hara yang tersedia bagi tanaman.

K- dd merupakan kalium yang tersedia dalam tanah. Ketersediaan kalium dalam tanah berhubungan erat dengan reaksi tanah dan status kejenuhan basa (KB). Pada $\mathrm{pH}$ dan kejenuhan basa rendah, ketersediaan kalium juga rendah. Nilai kritis kalium dalam tanah adalah 0,10 me/100 gr tanah (setara 3,9 mg/100 gr) atau sekitar 2-3\% jumlah basa tertukar (Hanafiah, 2005). Ketersediaan kalium yang rendah pada tanah akan mempengaruhi penyerapan kation yang dilakukan oleh akar sehingga penyerapan nitrogen terhambat sehingga kandungan $\mathrm{N}$-total tanah juga rendah menyebabkan tanaman tidak tumbuh secara maksimal (Novizan, 2005).

\section{Kapasitas Tukar Kation (KTK)}

Hasil KTK pada lokasi pertama nilai rata-rata pada lapisan top soil 12,15 (rendah), dan pada lapisan sub soil rata-rata 4,35 (sangat rendah), sedangkan pada lokasi kedua nilai rata-rata pada lapisan top soil 13,15 (rendah) dan pada lapisan sub soil rata-rata 19,05 (sedang) . Rendahnya KTK pada kedua lokasi diduga karena pada lokasi tersebut memiliki kandungan bahan organik yang rendah. Bohn (2009) menyatakan bahwa salah satu variabel yang mempengaruhi nilai KTK tanah adalah kandungan humus tanah dan jenis mineral tanah. Tanah yang diliputi oleh bagian oksida-hidrat $\mathrm{Al}$ dan Fe umumnya memiliki muatan negatif rendah pada permukaan koloid (Sposito, 2010), sehingga nilai KTK tanah biasanya rendah. Kondisi ini banyak dijumpai pada tanah mineral (lahan kering) yang terdapat pada kondisi iklim tropika basah, Sufardi et, al (1999). Kemudian, tanah dengan bahan alami sedang hingga tinggi sebagian besar memiliki KTK tanah yang umumnya lebih tinggi dari pada tanah dengan bahan organik rendah (Suriadikarta et al., 2002).

Nilai KTK yang rendah hanya mampu menyerap unsur hara yang rendah pula seperti kation-kation yang di peroleh dari hara makro dan mikro yang di perlukan oleh tanaman. 
Hardjowigeno (1992) menyatakan bahwa, tanah yang memiliki KTK yang tinggi mampu menyerap dan mempertukarkan kation-kation serta dapat menyediakan hara yang lebih baik dibandingkan dengan KTK yang lebih rendah, karena unsur hara yang tersedia tidak dengan mudahnya tercuci oleh air. Mukhlis et al, (2011) menyatakan bahwa, nilai KTK yang besar dapat ditentukan oleh beberapa faktor seperti jenis mineral liat, bahan organik serta tekstur pada tanah.

\section{Evaluasi Ketersediaan Hara pada Lahan Serewangi}

hasil analisis sifat kimia tanah pada lahan serewangi yang tumbuh bagus dan pada lahan serewangi yang tumbuh tidak bagus di Lamteuba Kecamatan Seulimum Aceh Besar tergolong kedalam kriteria yang berbeda berdasarkan masing-masing parameter. Hal ini diduga adanya faktor internal maupun eksternal yang dapat mempengaruhi pertumbuhan serewangi pada kedua lahan tersebut. Pertumbuhan tanaman dapat dipengaruhi oleh faktor internal dan eksternal, faktor internal seperti: hormon, kesimbangan air, genetik, sedangkan faktor eksternal seperti: iklim, pencemaran, temperatur, radiasi energi, ketersedian lengas, reaksi tanah, susunan gas dalam tanah dan ketersedian hara tanah (Bahidin dan Iwan, 2018).

Hasil survei dan wawancara dengan pengelola lahan tersebut, bedanya pertumbuhan serewangi pada kedua lokasi tersebut yaitu pada lahan serewangi yang tumbuh tidak bagus pertumbuhan gulma alang-alang sangat begitu cepat sehingga membuat petani sulit dalam mengendalikannya, pertumbuhan alang-alang yang begitu pesat membuat lahan tersebut menjadi semak belukar dan menyebabkan terjadinya persaingan unsur hara dengan tanaman serewangi, sehingga pertumbuhan serewangi menjadi terhambat dan tumbuh kerdil bahkan banyak yang mati.

Ketersediaan hara pada kedua lokasi tersebut tergolong sama, hanya saja pada lokasi kedua didominasi oleh gulma alang-alang yang membuat pertumbuhan serewangi pada lokasi kedua tidak tumbuh bagus. Berbeda dengan lokasi pertama yang pertumbuhan serewanginya tumbuh bagus, lahan tersebut tidak ditumbuhi gulma alang-alang karena lokasi ini sering di bersihkan oleh petani sehingga lebih mudah dalam merawat lahan tersebut, Pada lahan serewangi yang tumbuh bagus dilakukan juga penanaman tumpang sari yaitu dengan menanam pepaya, ubi jalar, dan tanaman lainya, sehingga ada beberapa ketersediaan hara yang lebih tinggi. Berbedanya pertumbuhan serewangi pada kedua lokasi dikarenakan adanya perbedaan dalam mengelola kedua lahan tersebut, pada lokasi pertama lahan sering dibersihkan dari gulma serta alang-alang yang tumbuh sehingga minim terjadinya perebutan unsur hara antara serewangi dan alang-alang. Sedangkan lahan pada lokasi kedua tidak adanya dilakukan pengelolaan seperti halnya pada lokasi pertama, sehingga lahan pada lokasi kedua lebih dominan ditumbuhi oleh semak belukar seperti alang-alang yang dapat mempengaruhi pertumbuhan serewangi yang ditanami pada lokasi tersebut. Sehingga terlihat secara fisik pertumbuhan serewangi pada lokasi kedua tidak tumbuh dengan bagus. Namun walaupun kedua lahan serewangi memiliki ketersediaan hara yang rendah akan tetapi tanaman serewangi dapat tumbuh dengan baik pada lahan-lahan kritis sekalipun.

\section{KESIMPULAN DAN SARAN}

Dari kedua lokasi budidaya tanaman serewangi memiliki ketersediaan hara yang sama yaitu tergolong kriteria rendah. Rata - rata kandungan hara di kedua lokasi di Desa Lamteuba adalah sebagai berikut: Lahan lokasi 1 (Pertumbuhan Bagus): $\mathrm{pH}=5,47, \mathrm{P}$-tersedia $=$ $24,14 \mathrm{ppm}, \mathrm{P}$-total $=7,84 \mathrm{mg} / 100 \mathrm{~g}, \mathrm{C}$-Organik $=2,19 \%, \mathrm{KTK}=12,15 \mathrm{me} / 100 \mathrm{~g}, \mathrm{~K}-\mathrm{dd}=$ $0,63 \mathrm{cmol} / \mathrm{kg}, \mathrm{N}$-total $=0,12 \mathrm{Kjhedal}$. Lahan lokasi 2 (Pertumbuhan Tidak Bagus): $\mathrm{pH}=5,63$, 
$\mathrm{P}$-tersedia $=23,83 \mathrm{ppm}, \mathrm{P}$-total $=8,03 \mathrm{mg} / 100 \mathrm{~g}, \mathrm{C}$-Organik $=1,56 \%, \mathrm{KTK}=13,15 \mathrm{me} / 100 \mathrm{~g}$, $\mathrm{K}-\mathrm{dd}=0,63 \mathrm{cmol} / \mathrm{kg}, \mathrm{N}$-total $=0,11 \mathrm{kjhedal}$. Perbedaan pertumbuhan tanaman serewangi pada lokasi 1 dan 2 disebabkan akibat perbedaan dalam pengelolaannya dan keadaan topografi yang berbeda. Disarankan untuk perbaikan lahannya, perlu adanya masukan berupa pupuk organik sehingga dapat meningkatkan kandungan hara yang ada pada lahan budidya tersebut sehingga mendapatkan hasil pertumbuhan yang lebih baik sesuai dengan yang diharapkan.

\section{DAFTAR PUSTAKA}

Atmaja, M. K., Tika, W., Wijaya, S. A. Md. I. 2017. Pengaruh Perbandingan Komposisi Bahan Baku terhadap Kualitas Kompos dan Lama Waktu Pengomposan. Jurnal BETA (Biosistem dan Teknik Pertanian), Volume 5, Nomor 1(Januari,2017). Program Studi Teknik Pertanian, Fakultas Teknologi Pertanian. Universitas Udayana. Bali

Bahidin Laode Mpapa dan Iwan Sudarmaji, 2018. Unsur Hara Tanah Dan Jaringan Tanaman Kehutanan Jenis Cepat Tumbuh Dan Lambat Tumbuh, Fakultas Pertanian Universitas Muhammadiyah, SSN 2337-7771 (Cetak) ISSN 2337-7992.

Barchia, M. F. 2009. Agroekosistem Tanah Mineral Asam. Gajah Mada University Press, Yogyakarta.

Bermanakusumah, Ramdhon. 1978. Erosi, Penyebab dan Pengendaliannya. Fakultas Pertanian Universitas Padjadjaran, Bandung.

Bohnet, Bernd. 2009. Efficient parsing of syntactic and semantic dependency structures. In Proceedings of CoNLL-09.

Damanik, P. 2007. Perubahan Kepadatan Tanah dan Produksi Tanaman Akibat Intensitas Lintasi Traktor dan Dosis Bokasi (skripsi). Fakultas Teknologi Pertanian, Institut Pertanian Bogor. Bogor.

Direktorat jendral Pendidikan Tinggi. 1991. Kesuburan Tanah. Departemen Pendidikan dan kebudayaan. Jakarta.

Djaenudin, D. (2008) Perkembangan Penelitian Sumber Daya Lahan dan Kontribusinya untuk Mengatasi Kebutuhan Lahan Pertanian di Indonesia. Jurnal Litbang Pertanian. 27 (4), 137-145.

Foth, H. D. 1994. Dasar-Dasar Ilmu Tanah. Edisi Keenam. Terjemahan S. Adisoemarto. Erlangga. Jakarta.

Hakim, N., M. Y. Nyakpa, A. M. Lubis, S. G. Nugroho, M. A. Diha, G. B. Hong, dan H. H. Bailey. 1986. Dasar-dasar Ilmu Tanah. Universitas Lampung. Bandar Lampung. 488 hlm.

Hanafiah, K. A. 2012. Dasar-Dasar Ilmu Tanah. PT Raja Grafindo Persada. Jakarta.

Hardjowigeno, S. 2007. Ilmu Tanah. Jakarta: Akademika Pressindo.

Hasibuan, B. E. 2008. Pengolahan Tanah dan Air Lahan Marjinal. Universitas Sumatera Utara. Medan.

Hitmatullah, dan Sukarman. 2007. Evaluasi Sifat-sifat Tanah Pada Landform Aluvial Di Kabupaten Donggala Sulawesi Tengah. Jurnal Tanah Dan Iklim. 25: 69-81.

Izzudin, 2012. Perubahan Sifat Kimia dan Biologi Tanah Pasca Kegiatan Perambahan di Areal Hutan Pinus Reboisasi Kabupaten Humbang Hasunduta Provinsi Sumatera Utara. Skripsi.

Joni Gunawan. 2013. Studi Kesuburan Tanah Pada Beberapa Penggunaan Lahan Di Desa Pangkal Baru Kecamatan Tempunak Kabupaten Sintang. Jurnal Sains Mahasiswa Pertanian. Vol 2, No 3. 
Mukhlis, Sarifuddin, dan H. Hamidah. 2011. Kimia Tanah Teori dan Aplikasi. USU Press, Medan.

Notohadiprawiro, T., 2006. Budidaya Organik: Suatu Sistem Pengusaha Lahan Bagi Keberhasilan Program Transmigrasi Pola Pertanian Lahan Kering. Repro: Ilmu Tanah UGM-Yogjakarta. h: 1-10.

Novizan. 2005. Petunjuk Pemupukan yang Efektif. Agromedia Pustaka. Jakarta.

Perdanatika, A., Suntoro, S. and Pardjanto, P. 2018. The Effects of Rice Husk Ash and Dolomite on Soybean Yield at Latosol Soil. Sains Tanah - Journal of Soil Science and Agroclimatology. 15 (1), 29.

Pusat Penelitian Tanah. 1999. Survey kapabilitas tanah dalam klasifikasi kesesuaian lahan. Term of Reference. Type A. No. 59/1983. P3MT. PPT. Bogor. Indonesia.

Puslittanak. 2003. Usahatani pada Lahan Kering, Badan Penelitian dan Pengembangan Pertanian Departemen Pertanian, Bogor.

Sposito, G. 2010. The chemistry of soils. Oxford Univ. Press., London.

Sufardi, A.D. Dyakusuma, T.S. Hasan. 1999. Perubahan Karakteristik Muatan dan Retensi Fosfor Ultisol Akibat Pemberian Amelioran dan Pupuk Fosfat. Konggres Nasional VII. HITI. Bandung.

Suriadikarta, D.A., T. Prihatini, D. Setyorini, dan W. Hartatiek. 2002. Teknologi pengelolaan bahan organik tanah. hlm. 183-238. Dalam Teknologi Pengelolaan Lahan Kering Menuju Pertanian Produktif dan Ramah Lingkungan. Pusat Penelitian dan Pengembangan Tanah dan Agroklimat, Bogor.

Sutandi, I. 2011. Air Tanah. Skripsi. Bandung: Fakultas Teknik, Universitas Kristen Maranatha. Suwondo, S. Sabihan, Sumardjo, dan B. Paramudya. 2010. Analisis Lingkungan Biofisik Lahan Gambut Pada Perkebunan Kelapa Sawit. Jurnal Hidrolitan. 1(3): 20-28.

Widianto, Hairiah, Suharjito, Sardjono. 2013. Fungsi Dan Peran Agroforestry. World Agroforestry Center (ICRAF).

Winarso, S. 2005. Kesuburan Tanah: Dasar Kesehatan dan Kualitas Tanah. Gava media. Jogjakarta. 269 hal. 